\title{
Petrologic Constraints on the Unroofing History of the Funeral Mountain Metamorphic Core Complex, California
}

\author{
K.V. HODGES \\ Department of Earth, Almospheric, and Planetary Sciences, Massachusetts Institute of Technology, Cambridge \\ J.D. WALKER \\ Department of Geology, University of Kansas, Lawrence
}

\begin{abstract}
The northem Funeral Mountains, southeastem Califomia, comprise a metamorphic core complex that lies within a region of extreme Neogene extension but did not experience a significant late Cenozoic thermal event. This circumstance, unusual among core complexes of the North American Cordillera, permits direct examination of the preextensional thermal evolution of a portion of the Cordilleran hinterland. For pelitic schists from the highest-grade portions of the Funeral metamorphic core, thermobarometry and thermodynamic modeling of gamet zonation define a P-T trajectory showing: (1) attainment of "peak" metamorphic conditions at 800-850 K and 800-1000 MPa (30-37 km depths); followed by (2) 400 to $600 \mathrm{MPa}$ of decompression (15-22 km of exhumation) with no substantial change in temperature. Available geochronologic data indicate that peak metamorphism occurred in Early Cretaceous time and that the decompression path developed over the Early to Late Cretaceous interval. The maximum pressures indicated by the petrologic data require substantial Late Jurassic(?) - Early Cretaceous tectonic burial even though most recognized thrust faults at this latitude that have large stratigraphic throws are assumed or demonstrated to have early Mesozoic ages. We postulate that post-Early Cretaceous extensional faults may have excised the necessary middle Mesozoic thrust structures. While the majority of extensional structures responsible for this excisement is likely to be of Neogene age, associated with Basin and Range extension, the Cretaceous decompression path described in this paper is similar to the theoretical P-T paths derived from numerical modeling of extensional unroofing. Given recent evidence for the development of extensional structures in compressional regimes like the Himalayan and Alpine orogens, it seems prudent to search for evidence of Mesozoic extensional structures in future studies of the hinterland of the North American Cordillera.
\end{abstract}

\section{INTRODUCTION}

Metamorphic core complexes represent the deepest exposed levels of the compressional orogen that characterized western North America in Mesozoic time [Armstrong, 1982; Anderson et al., 1988]; consequently, they offer an excellent opportunity to examine the thermal evolution of the Cordilleran hinterland. Unfortunately, the thermal effects of Tertiary extension were so severe in many of the core complexes that evidence of the Mesozoic pressure-temperature history has been obscured or obliterated. The Funeral Mountains of southeastem California (Figure 1) are unusual in this regard because available geochronologic data indicate no important Tertiary thermal events in the core complex despite significant Neogene extension in the region [DeWitt et al., 1988; Wernicke et al., 1988a]. We have studied a collection of pelitic schist samples from the high-grade portions of the Funeral Mountains in an effort to constrain the Cretaceous pressure-temperature evolution of the range. In this paper, we report the results of our research and discuss their implications for the tectonic evolution of the Death Valley region.

\section{Geologic SETTING}

The Funeral Mouintains consist of a metamorphic core overlain structurally by upper Proterozoic to Tertiary

Copyright 1990 by the American Geophysical Union.

Paper number 89JB03310.

0148-0227/90/89JB-03310\$05.00 sedimentary and volcanic units [Troxel, 1988] (Figure 2). The contact between these structural packages is marked by a diachronous system of extensional structures: the Boundary Canyon detachment on the north and northwest, and the younger, predominantly dextral Keane Wonder fault on the west [Troxel and Wright, 1989]. Geochronologic and stratigraphic constraints indicate that both structures developed in the last 9 m.y. [Reynolds et al., 1986].

The metamorphic core of the range includes (1) amphibolitic, granitic, and pelitic gneisses of early Proterozoic(?) age; (2) metasedimentary rocks of late Proterozoic-Cambrian age; (3) muscovite-bearing granitoid rocks of Cretaceous age; and (4) pegmatitic granites of probable middle Tertiary age [Troxel, 1988; Wasserburg et al., 1959; DeWitt et al., 1988]. Pre-Cretaceous units contain mineral assemblages indicative of upper greenschist to upper amphibolite facies metamorphism; in general, the degree of metamorphism increases from southeast to northwest and reaches a maximum (kyanite \pm sillimanite + gamet + biotite) in early Proterozoic(?) gneisses and upper Proterozoic metasedimentary units near the mouth of Monarch Canyon (Figure 2) [Labotka, 1980].

The age of regional metamorphism in the Funeral Mountains is constrained by ${ }^{40} \mathrm{Ar}-{ }^{39} \mathrm{Ar}$ mineral ages obtained by DeWitt et al. [1988]. Although most of the spectra indicated an extraneous argon component, hornblende samples with $\mathrm{K}_{2} \mathrm{O}>0.6 \mathrm{wt} \%$ consistently yielded plateau ages of 130 $115 \mathrm{Ma}$. Plateau ages for muscovites ranged from 110 to 55 $\mathrm{Ma}$, the youngest ages being obtained for metamorphic muscovites from samples collected near Upper Cretaceous 


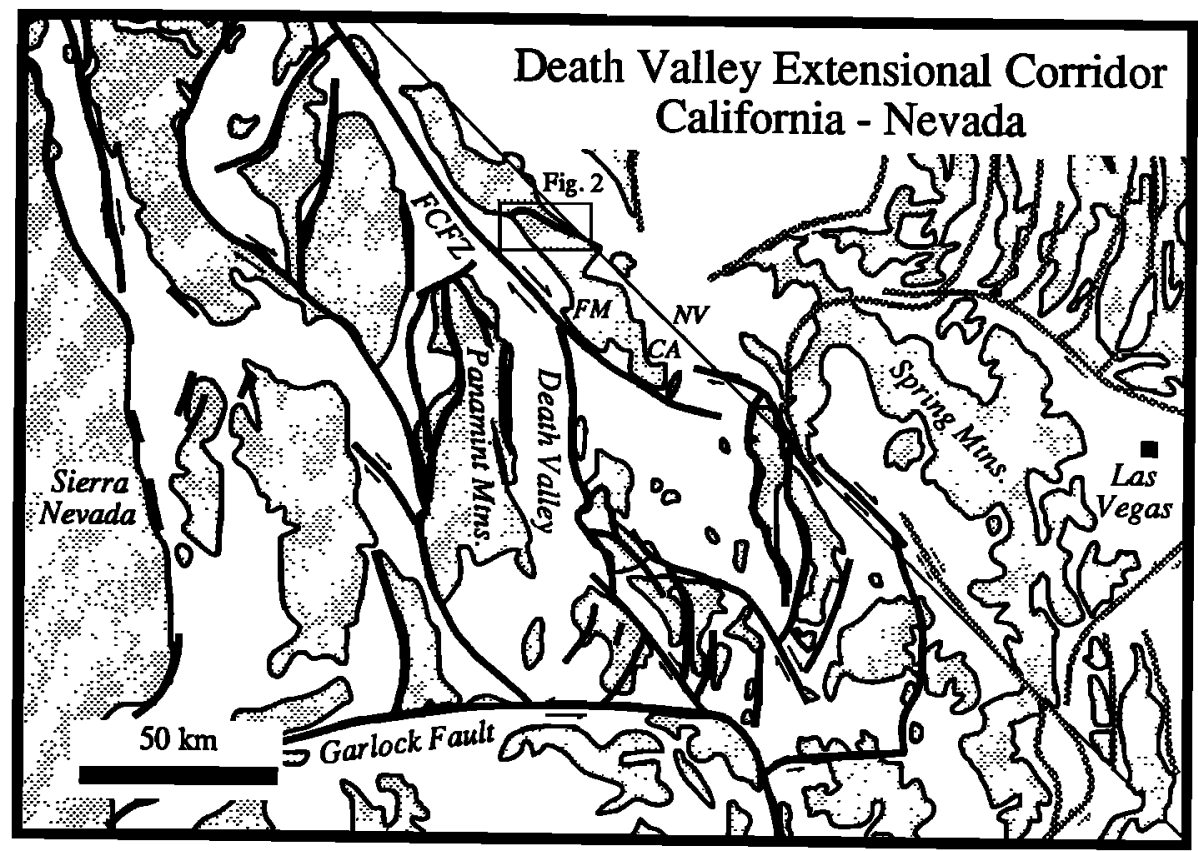

Fig. 1. Simplified tectonic map of the Death Valley extensional corridor, California-Nevada. FM indicates the position of the Funeral Mountains. Rectangle shows the location of Figure 2.

granitic bodies. DeWitt et al. [1988] interpreted these data in terms of Early Cretaceous regional metamorphism and a Late Cretaceous thermal pulse associated with granite intrusion. The absence of post-early Eocene muscovite ages in the Funeral Mountains strongly suggests that the metamorphic core had cooled well below the closure temperature for $\mathrm{Ar}$ in muscovite ( 625K [Jäger, 1979]) prior to Neogene extension in the Death Valley region.

\section{SAMPLe Selection and Characteristics}

In metamorphic terrains exhibiting a variety of facies types, thermobarometric studies in rocks of different
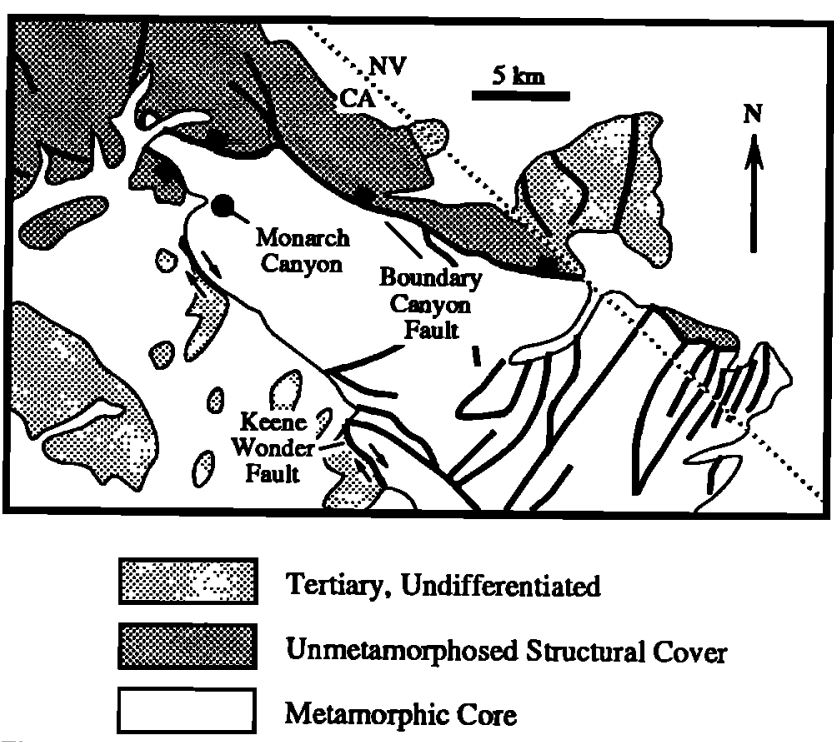

Fig. 2. Simplified tectonic map of the northern end of the Funeral Mountains (after Troxel and Wright [1989]). Solid circle indicates the sampling area in lower Monarch Canyon. metamorphic grade provide information about different periods in the thermal evolution of the area. For example, lower-grade assemblages record more of the prograde history than do higher-grade assemblages, whereas higher-grade assemblages are better recorders of retrograde processes after the metamorphic peak [Hodges and Royden, 1984]. For this study, we were most interested in the unroofing history of the Funeral Mountains. Consequently, we focussed our research on the highest grade portions of the metamorphic core.

After examining a large number of pelitic samples petrographically, we selected seven for detailed thermobarometric study: FM-2, FM-12, FM-14, FM-16, FM17, FM-18, and FM-20. Sample FM-2 is a schist from the Upper Proterozoic Crystal Spring Formation. The other samples are pelitic gneisses from the basement complex of presumed early Proterozoic age [Troxel and Wright, 1989]. All samples were collected from the lower reaches of Monarch Canyon (Figure 2), and they represent a single structural level to within roughly $100 \mathrm{~m}$. There is continuous outcrop between the sample localities, and no major postmetamorphic structural discontinuities were observed. Granitic sills and dikes of various ages occur in lower Monarch Canyon; the most abundant are weakly deformed, muscovite granites of probable Late Cretaceous age (E. DeWitt, personal communication, 1988). Samples FM-14 and FM-18 were collected adjacent to one of these bodies. Other samples were collected from outcrops greater than $5 \mathrm{~m}$ away from the granites.

The modal mineralogy of the Monarch Canyon samples is indicated in Table 1. The samples contain three deformational fabrics: (1) an early schistosity present as inclusion trails in garnet, staurolite, and kyanite porphyroblasts $\left(S_{i}\right)$; $(2)$ the predominant schistosity defined by micas $\left(S_{1}\right)$; and (3) late kink bands best developed in biotite and kyanite. Timing relationships between fabric development and porphyroblast growth are shown in Figure 3. Although all samples were collected from the high grade side of the kyanite + gamet + 
TABLE 1. Modal Mineralogy

\begin{tabular}{|c|c|c|c|c|c|c|c|}
\hline & FM-6 & FM-12 & FM-14 & FM-16 & FM-17 & FM-18 & FM-20 \\
\hline Quartz & $\bullet$ & $\bullet$ & $\bullet$ & $\bullet$ & $\bullet$ & $\bullet$ & $\bullet$ \\
\hline Muscovite & - & - & - & - & - & • & - \\
\hline Biotite & - & • & - & • & - & $\bullet$ & • \\
\hline Gamet & - & - & • & • & $\bullet$ & - & • \\
\hline Plagioclase & • & - & • & - & $\bullet$ & • & • \\
\hline Kyanite & - & - & • & - & - & • & - \\
\hline Staurolite & $\mathbf{x}$ & $\mathbf{i}$ & - & - & - & - & $x$ \\
\hline Chlorite & $x$ & - & - & - & - & - & - \\
\hline Rutile & $\bullet$ & - & $x$ & $\mathbf{x}$ & - & $x$ & $x$ \\
\hline Imenite & $\mathbf{x}$ & - & $\bullet$ & - & $\bar{x}$ & $x$ & $\cdot$ \\
\hline
\end{tabular}

Solid circles, present in sample; crosses, absent in sample; $i$, present only as inclusions in muscovite.

biotite isograd defined by Labotka [1980], the majority contained staurolite as part of the basic prograde assemblage that was stable during the development of Si and S1: gamet + biotite + kyanite + muscovite + quartz + plagioclase. Six of the samples showed evidence of minor, relatively low-temperature retrogression, including the spotty development of chlorite reaction rims on gamet and white mica reaction rims on kyanite. Petrographic study of other Monarch Canyon samples indicated that the degree of low-temperature retrogression varies greatly from outcrop to outcrop.

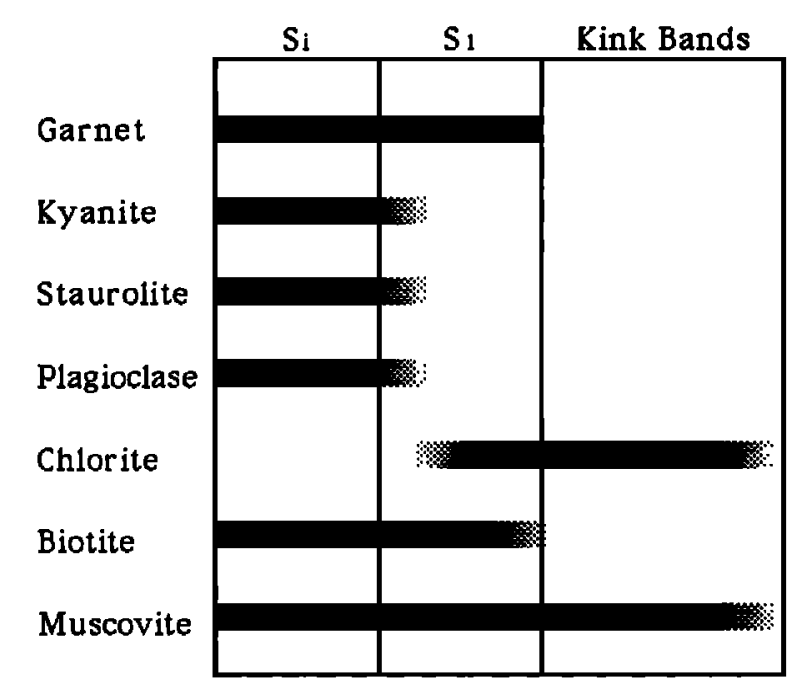

Fig. 3. Timing relationships between petrofabrics and principal porphyroblast growth.

\section{THERMOBAROMETRY}

The mineral assemblages observed in the Monarch Canyon samples are appropriate for the application of several pelitic thermobarometers. For this study, we chose to use three experimentally calibrated equilibria:

$$
\begin{aligned}
& \mathrm{Mg}_{3} \mathrm{Al}_{2} \mathrm{Si}_{3} \mathrm{O}_{12}+\mathrm{KFe}_{3} \mathrm{AlSi}_{3} \mathrm{O}_{10}(\mathrm{OH})_{2}= \\
& \text { garnet biotite } \\
& \mathrm{Fe}_{3} \mathrm{Al}_{2} \mathrm{Si}_{3} \mathrm{O}_{12}+\mathrm{KMg}_{3} \mathrm{AlSi}_{3} \mathrm{O}_{10}(\mathrm{OH})_{2} \\
& \text { garnet biotite } \\
& \mathrm{Ca}_{3} \mathrm{Al}_{2} \mathrm{Si}_{3} \mathrm{O}_{12}+2 \mathrm{Al}_{2} \mathrm{SiO}_{5}+\mathrm{SiO}_{2}= \\
& \text { garnet kyanite quart } \\
& 3 \mathrm{CaAl}_{2} \mathrm{SiO}_{8} \\
& \text { plagioclase }
\end{aligned}
$$

$$
\begin{aligned}
& 3 \mathrm{FeTiO}_{3}+\mathrm{Al}_{2} \mathrm{SiO}_{5}+2 \mathrm{SiO}_{2}= \\
& \text { ilmenite kyanite quartz } \\
& \mathrm{Fe}_{3} \mathrm{Al}_{2} \mathrm{Si}_{3} \mathrm{O}_{12}+3 \mathrm{TiO}_{2} \\
& \text { garnet rutile }
\end{aligned}
$$

GARB describes $\mathrm{Fe}$ and $\mathrm{Mg}$ partitioning between coexisting garnet and biotite and is very strongly temperature dependent. GASP and GRAIL describe the pressure dependency of $\mathrm{Ca}$ partitioning between garnet and plagioclase and $\mathrm{Fe}$ partitioning between ilmenite and garnet, respectively. GASP is substantially more temperature dependent than is GRAIL: the nominal Clapyron slope for GASP is $2.2 \mathrm{MPa} / \mathrm{deg}$ compared to $1.0 \mathrm{MPa} / \mathrm{deg}$ for GRAIL [Hodges and McKenna, 1987; McKenna and Hodges, 1988]. Consequently, paleopressure estimates made using GASP are generally less precise than those made using GRAIL. Unfortunately, only sample FM-12 contained the GRAIL assemblage.

Experimental calibrations for the reactions considered here include (1) Ferry and Spear [1978] for GARB; (2) Hays [1966], Hariya and Kennedy [1968], Goldsmith [1980], Gasparik [1984], and Koziol and Newton [1988] for GASP; and (3) Bohlen et al. [1983] for GRAIL. In this paper, we will use the thermodynamic constants derived from these experiments by Hodges and McKenna [1987] for GARB and GRAIL and those derived by McKenna and Hodges [1988] for GASP. The use of other values derived through different statistical treatments of the same experimental data sets would not substantially alter our results.

Rim compositions of garnet, biotite, muscovite, and plagioclase in all samples (as well as ilmenite in FM-12) were analyzed using the JEOL 733 Superprobe at the Massachusetts Institute of Technology. Pertinent mole fractions and uncertainties (reported at the 95\% confidence level) for these phases (Table 2) were calculated using the approach described by Hodges and McKenna [1987]. Measured rim compositions were very consistent across the analyzed probe mounts for each section, suggesting a close approach to equilibrium.

Final equilibration conditions for all samples were estimated through simultaneous solution of GARB and GASP (Table 3 and Figure 4) using the solution models described by Hodges and Royden [1984]. For sample FM-12, simultaneous solution of GARB and GRAIL yields a pressure and temperature well within analytical uncertainty for the GARB-GASP solution (Table 3). As expected, all P-T estimates plot within the kyanite stability field of Holdaway [1971]. Although equilibration temperatures show limited variation between samples, the range of recorded pressures is $425 \mathrm{MPa}$. This range far exceeds the 2-s precision limits for individual samples and cannot be explained by analytical uncertainty. 


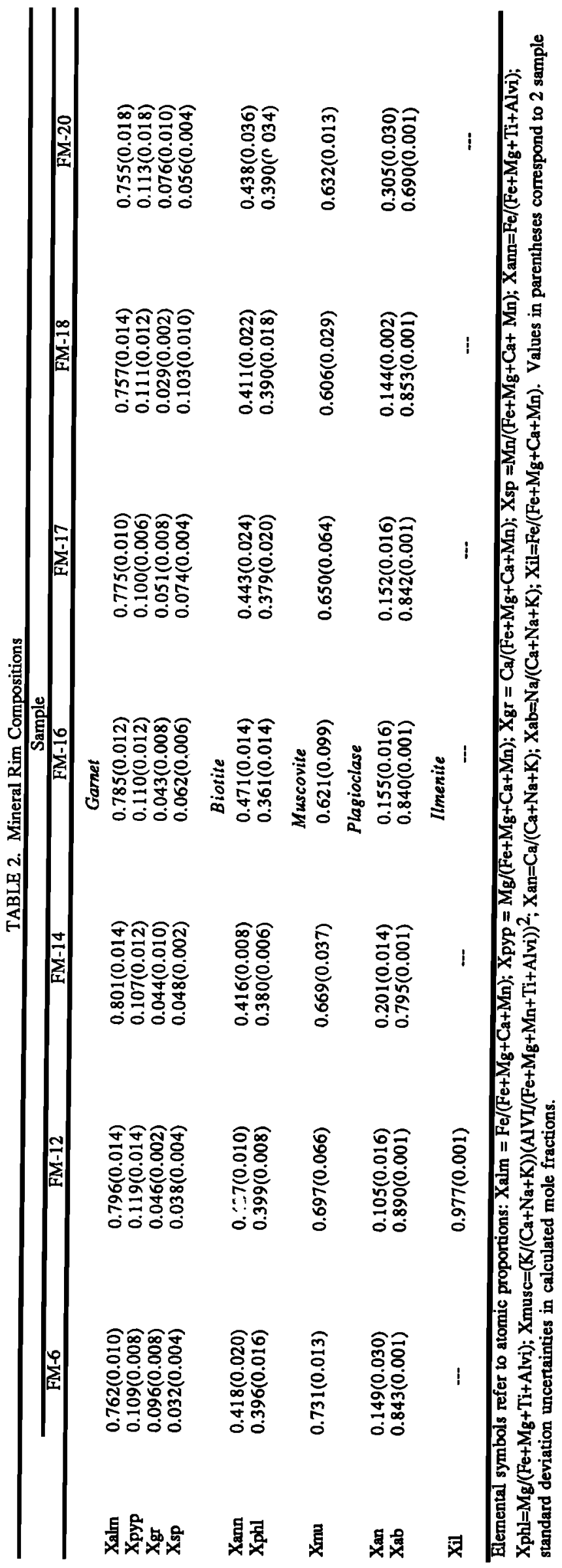

\begin{tabular}{lllcc}
\multicolumn{5}{c}{ TABLE 3. Thermobarometric Results } \\
\hline & \multicolumn{2}{c}{ GARB-GASP } & \multicolumn{3}{c}{ GARB-GRAII } \\
\cline { 2 - 5 } & T, K & P, MPa & T, K & P, MPa \\
\hline FM-6 & $\mathbf{8 0 3 ( 2 2 )}$ & $\mathbf{8 5 9 ( 8 5 )}$ & --- & -- \\
FM-12 & $\mathbf{8 1 0 ( 4 8 )}$ & $\mathbf{7 1 0 ( 1 1 8 )}$ & $\mathbf{8 1 1 ( 3 1 )}$ & $\mathbf{7 3 9 ( 4 6 )}$ \\
FM-14 & $771(42)$ & $\mathbf{4 3 4 ( 9 5 )}$ & -- & -- \\
FM-16 & $\mathbf{8 5 1 ( 4 3 )}$ & $\mathbf{6 4 6 ( 1 0 2 )}$ & -- & -- \\
FM-17 & $\mathbf{7 8 9 ( 2 1 )}$ & $\mathbf{5 9 0}(95)$ & -- & -- \\
FM-18 & $\mathbf{7 8 8 ( 2 6 )}$ & $\mathbf{4 3 9 ( 6 1 )}$ & -- & -- \\
FM-20 & $\mathbf{8 2 2 ( 6 2 )}$ & $\mathbf{5 8 2 ( 1 3 0 )}$ & -- & -- \\
\hline
\end{tabular}

Numbers in parentheses indicate 2 standard deviation precision cal culated using the method of Hodges and McKenna [1987].

Compared to the earlier work of Labotka [1980], who estimated conditions of 875-975 $\mathrm{K}$ and 720-960 MPa for the Monarch Canyon area using GARB-GASP, our findings indicate greater variability between samples at a given structural level and substantially lower temperatures and pressures. We attribute much of the discrepancy between the two data sets to advancements in our understanding of garnet solution behavior and to improvements in the experimental calibration of GASP.

\section{P-T Paths Modeled From Garnet ZoNING}

Garnet porphyroblasts in the Monarch Canyon samples show relatively little compositional zoning, but slight variations in zoning profiles correlate with the pressure variations in Table 3. Figure 5 illustrates the range in observed profiles. Garnets in sample FM-6, which yields the highest equilibration pressure, have the least significant variations in core-rim compositions: $X_{g r}$ and $X_{\text {sp }}$ are essentially constant while $\mathrm{Fe} / \mathrm{Mg}$ varies from roughly 4.8 at the core to 7.0 at the rim. Samples with progressively lower equilibration pressures show slightly greater core-rim variations in $\mathrm{Fe} / \mathrm{Mg}$, with a maximum of 4.5 to 7.5 for FM-14.

Many of the Monarch Canyon garnets contain biotite and plagioclase inclusions that have higher $X_{p h l}$ and $X_{a b}$, respectively, than the rims of their matrix counterparts. These

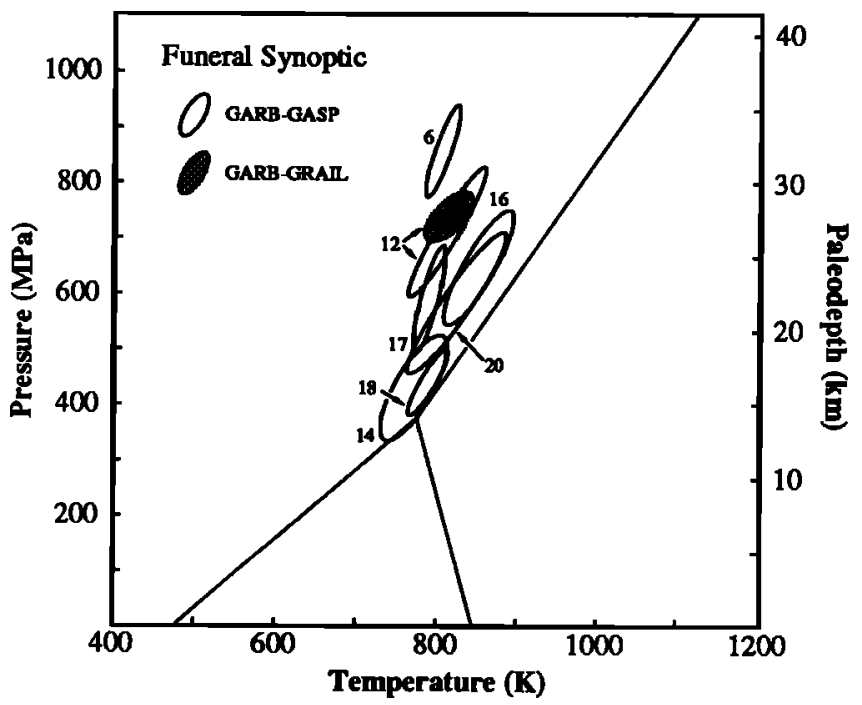

Fig. 4. Thermobarometric data for the Funeral Mountains samples (FM prefix ommitted for clarity). Ellipses indicate $95 \%$ confidence fields for simultaneous solutions of the GARB and GASP (unpattemed) or GARB and GRAIL (shaded) equilibria. Aluminum silicate stability fields are shown [Holdaway, 1971]. Note that samples FM-14 and FM18 were collected near Late Cretaceous(?) granitic plutons. 

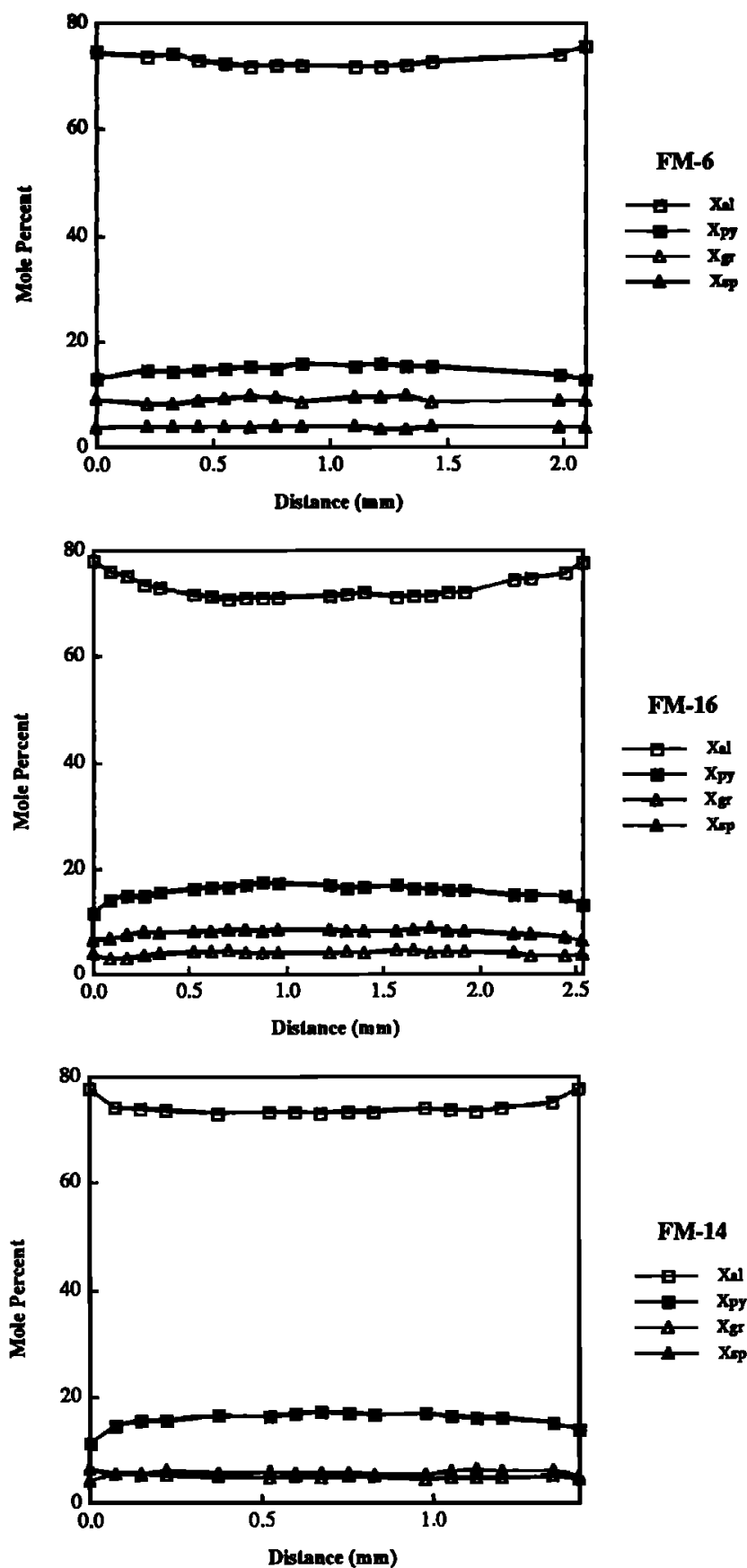

Fig. 5. Major element zoning profiles for the largest garnets in samples FM-6, FM-16, and FM-14. Mole fraction abbeviations are defined in Table 2.

inclusions permit application of the Gibbs' Method approach of Spear and Selverstone [1983] in an effort to model the direction and magnitude of P-T variations indicated by gamet zoning in samples FM-12, FM-14, FM-17, FM-18, and FM-20. For this purpose, we assumed that the samples could be modeled in the system $\mathrm{K}_{2} \mathrm{O}-\mathrm{CaO}-\mathrm{Na}_{2} \mathrm{O}-\mathrm{FeO}-\mathrm{MnO}-\mathrm{MgO}-\mathrm{Al}_{2} \mathrm{O}_{3}-\mathrm{SiO}_{2}-$ $\mathrm{H}_{2} \mathrm{O}$ and that the model assemblage garnet + biotite + muscovite + plagioclase + quartz + kyanite + water was stable throughout the interval over which the garnet zoning developed. These assumptions result in a thermodynamic variance of four, such that changes in $X_{a l m}, X_{g r}, X_{s p}$ in garnet, along with differences in $X_{a n n}$ or $X_{a n}$ between matrix phases and inclusions of either biotite or plagioclase could be used to model $\Delta \mathrm{P}$ and $\Delta \mathrm{T}$ (Table 4). Although the modeled paths display some variation in the sign and magnitude of corerim $\Delta T$, all gamets indicate substantial decompression during their compositional evolution (Figure 6).

\section{INTERPRETATION OF PETROLOGIC DATA}

The variation in final equilibration pressures shown in Figure 4 could be interpreted in several ways. It is tempting to suggest that postmetamorphic faults in Monarch Canyon have juxtaposed samples which were metamorphosed at variable depths. We feel that this interpretation is implausible because (1) the existing map of the area [Troxel and Wright, 1989] and our observations reveal no appropriate structures; (2) there is no variation in the geometry of mesoscopic and microscopic synmetamorphic fabrics between sample locations; and (3) there is no straightforward relationship between sample location and calculated pressure.

A second possibility is that some or all of the P-T estimates are spurious as a consequence of disequilibrium between the phases used for thermobarometry. It is effectively impossible to prove that measured mineral compositions in any sample reflect equilibrium conditions, but the observed consistency of rim compositions in each Monarch Canyon sample and the corroboration of GASP by GRAIL in sample FM-12 argue against significant disequilibrium.

It is also possible that non-systematic variations in the chemistry of phases involved in the thermobarometric calculations affected some of the P-T estimates. For example, Indares and Martignole [1985] suggested that significant Ti and $\mathrm{A} 1 \mathrm{VI}$ substitution in biotite can substantially effect the accuracy of GARB geothermometry. Such errors also have a important effect on pressures calculated by simultaneously solving GASP and GARB because of the relatively high $d P / d T$ slope of GASP. For the Funeral Mountains samples, the mole fractions of $\mathrm{Ti}$ and $\mathrm{Al}$ in the octahedral site of biotite range from 0.037 to 0.052 and 0.126 to 0.156 , respectively. These limited variations suggest that empirical corrections for $\mathrm{Ti}$ and $\mathrm{Al}^{\mathrm{VI}}$ such as those suggested by Indares and Martignole [1985] would not significantly lessen the observed variability in equilibration P-T. Moreover, regressions of $\mathrm{X}_{\mathrm{Ti}}$ and $\mathrm{X}_{\mathrm{AIVI}}$ versus estimated temperature and pressure suggest little correlation, given reasonable uncertainties in the parameters involved.

We believe that the scatter in Monarch Canyon pressures indicates that different samples equilibrated at different P-T conditions (and therefore at different times) during the unroofing history of the core complex [cf. Hodges and Royden, 1984]. This interpretation is corroborated by the P-T paths suggested by Gibbs' method modeling for individual samples (Figure 6); for example, FM-18 records the second lowest rim pressure but yields a P-T path that extends to the approximate P-T conditions of FM-6, the sample that records the highest rim pressure. The observation that samples collected near late stage granites (FM-14 and FM-18) yield the lowest rim equilibration pressures while the sample collected the greatest distance away from these intrusives (FM-6) records the highest pressure implies that reequilibration of samples near the lowpressure end of the P-T trajectory may have been triggered in part by the thermal pulse associated with intrusion of the granites. The preservation of Early Cretaceous mica and amphibole ${ }^{40} \mathrm{Ar}-{ }^{39} \mathrm{Ar}$ ages in samples collected only a few 
TABLE 4. Gibbs' Method P-T Path Models

\begin{tabular}{|c|c|c|c|c|c|}
\hline Sample & Model Assemblage & Variance & Monitors & DT(K) & DP(MPa) \\
\hline FM-12 & $\mathrm{gr}+\mathrm{bi}+\mathrm{mu}+\mathrm{pg}+\mathrm{q}+\mathrm{k}+\mathrm{H}_{2} \mathrm{O}$ & 4 & $\begin{array}{l}\text { gr + bi inc. } \\
\text { gr + bi inc. } \\
\text { gr + bi inc. } \\
\text { net path }\end{array}$ & $\begin{array}{l}-1 \\
+51 \\
-55 \\
-5\end{array}$ & $\begin{array}{l}+57 \\
+37 \\
+135 \\
+229\end{array}$ \\
\hline FM-14 & $g r+b i+m u+p g+q+k+H_{2} 0$ & 4 & gr + bi inc. & +37 & +262 \\
\hline FM-17 & $\mathrm{gr}+b i+m u+p g+q+k+\mathrm{H}_{2} \mathrm{O}$ & 4 & $\begin{array}{l}g r+p g \text { inc. } \\
g r+b i \text { inc. } \\
\text { net path }\end{array}$ & $\begin{array}{l}+87 \\
-76 \\
+11\end{array}$ & $\begin{array}{l}+215 \\
+234 \\
+449\end{array}$ \\
\hline FM-18 & $\mathrm{gr}+\mathrm{bi}+\mathrm{mu}+\mathrm{pg}+\mathrm{q}+\mathrm{k}+\mathrm{H}_{2} \mathrm{O}$ & 4 & $\begin{array}{l}\text { gr + bi inc. } \\
\text { gr + bi inc. } \\
\text { gr + bi inc. } \\
\text { gr + bi inc. } \\
\text { net path }\end{array}$ & $\begin{array}{l}-9 \\
-9 \\
-6 \\
+4 \\
-20\end{array}$ & $\begin{array}{l}+184 \\
+54 \\
+126 \\
+18 \\
+382\end{array}$ \\
\hline FM-20 & $g r+b i+m u+p g+q+k+H_{2} \mathrm{O}$ & 4 & $\begin{array}{l}\text { gr + pg inc. } \\
\text { gr + pg inc. } \\
\text { net path }\end{array}$ & $\begin{array}{l}+60 \\
+25 \\
+85\end{array}$ & $\begin{array}{l}+93 \\
+36 \\
+129\end{array}$ \\
\hline
\end{tabular}

For model assemblages: gr, gamet; bi , biotite; mu , muscovite; Pg, plagioclase; q, quartz; k, kyanite. For monitors, gr: DXalm, DXgr, and DXsp derived from the difference between gamet rim composition and that measured at an inclusion; bi inc.: DXann derived from the difference between biotite rim composition and that measured for a biotite inclusion; pg inc.: DXan derived from the difference between plagioclase rim composition and that measured for a plagioclase inclusion. Multiple monitored inclusions are listed in order of relative distance from rim toward core. Net path indicates the cumulative DT-DP for all monitored inclusions.

meters away from these Late Cretaceous granites argues that this thermal pulse was very localized [DeWitt et al., 1988]; consequently, we interpret the rim equilibration conditions of FM-6 and the highest P-T values implied by Gibbs' method modeling as representative of Early Cretaceous peak metamorphic conditions.

Our perception of the thermal evolution of the Monarch Canyon area is illustrated schematically in Figure 7. Path A represents the P-T history of a sample that was initially metamorphosed in Early Cretaceous time but maintained temperatures in excess of $775 \mathrm{~K}$ over much of Cretaceous time as a consequence of episodic granitic intrusion. Its hightemperature decompression path approaches the kyanite = sillimanite transition; although none of the samples examined in this study contained sillimanite, some Monarch Canyon samples (notably those collected in the immediate vicinity of granite dikes and sills) contain late fibrolite [Labotka, 1980]. A sample tracking on path $A$ does not cool below the muscovite closure temperature until roughly $75 \%$ of its overburden has been removed. We interpret the Paleocene-

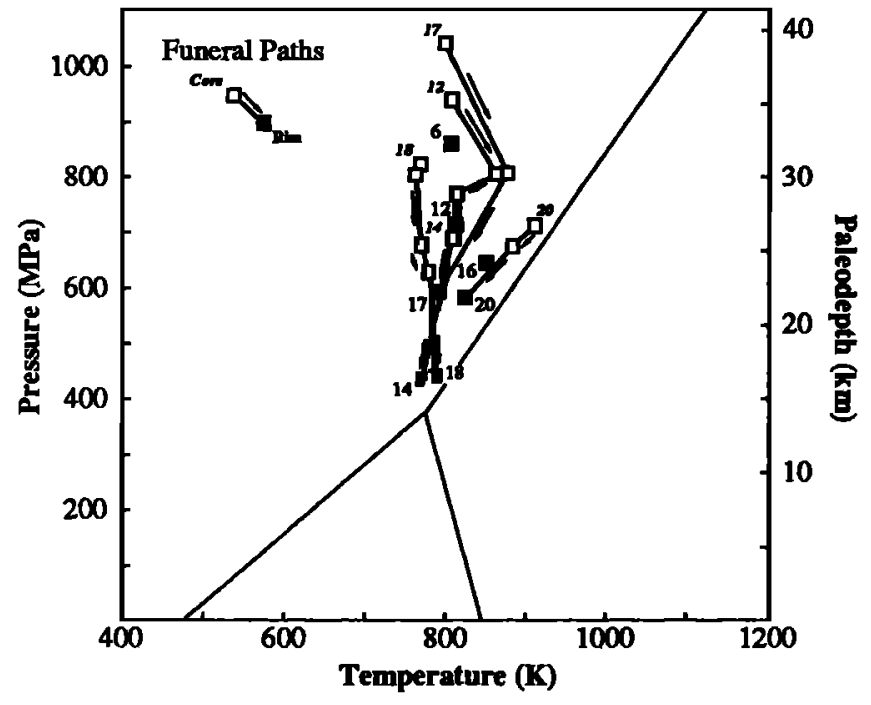

Fig. 6. Thermodynamic modeling results for the Funeral Mountains samples. Solid squares indicate calculated equilibration conditions for mineral rims. Open squares indicate points on the modeled P-T paths that are constrained by inclusion data. Arrows indicate progression from gamet interiors to rims. Larger sample labels, with FM prefix omitued, indicate rim P-T; smaller labels mark P-T conditions suggested by inclusions most distant from the gamet rims.

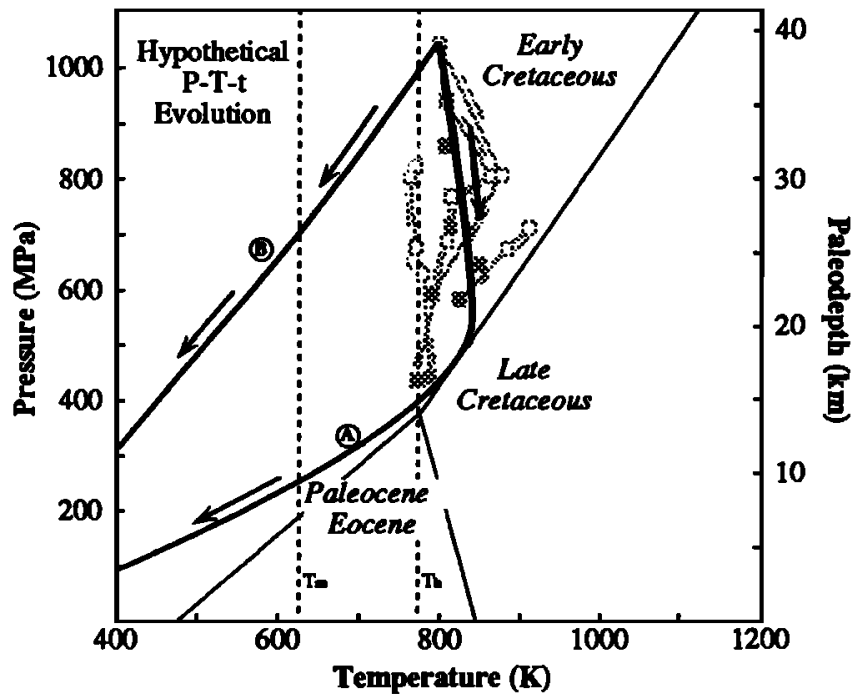

Fig. 7. Interpretive P-T paths for the Monarch Canyon area. Path $A$ holds for samples in the area of granitic intrusion like those analyzed in this study (shown in gray for reference). Path B, entirely hypothetical, holds for samples unaffected by the thermal pulse associated with Cretaceous granite intrusion. Constant time lines are parallel to the temperature axis on this diagram. Approximate Ar closure temperatures for homblende (Th) and muscovite (Tm) are indicated for reference. See text for further explanation. 
Eocene Ar muscovite cooling ages of DeWitt et al. [1988] as indicative of cooling along such a path.

Although all of the petrologic data obtained in this study imply unroofing along a trajectory similar to path $A$, the 130$115 \mathrm{Ma}$ homblende plateau ages and Albian muscovite plateau ages reported by DeWitt et al. [1988] suggest that Monarch Canyon samples located some distance away from the granites (and not subject to their thermal effects) may have had trajectories more similar to path $B$. There is no thermobarometric evidence that peak temperatures during the Early Cretaceous event were substantially greater than $\mathbf{8 0 0 - 8 5 0}$ $\mathrm{K}$, only $25^{\circ}-75^{\circ}$ higher than the nominal closure temperature for Ar diffusion in homblende [Jäger, 1979]. A sample evolving along path $B$ cools below this closure temperature early in its unroofing history, and it is never subsequently reheated.

Taken in conjunction with available geochronologic constraints, the petrologic data presented in this paper indicate roughly $400-600 \mathrm{MPa}$ of decompression, corresponding to 15 $22 \mathrm{~km}$ of unroofing, during the Early to Late Cretaceous interval in the Monarch Canyon area. Where the thermal effects of Cretaceous magmatic injection are strongest, temperatures do not appear to have varied by more than $100 \mathrm{~K}$ over the unroofing period; significant cooling of these horizons did not occur until the majority of unroofing had been accomplished.

\section{Tectonic Mechanisms for Early Cretaceous High-Pressure METAMORPHISM}

Although Mesozoic metamorphism in the Funeral Mountains was almost certainly broadly related to development of the Sierran arc [Labotka and Albee, 1988], the cause of the tectonic burial required by paleopressures in excess of $800 \mathrm{MPa}$ is enigmatic. Widespread Tertiary extensional deformation has clouded our understanding of the Mesozoic tectonic architecture of the Death Valley region. Recent attempts to reconstruct the region to its preextensional structural configuration have been based on correlations of Mesozoic fold and thrust geometries as well as isopach and facies trends in Precambrian to Paleozoic strata [Stewart, 1983, Wernicke et al., 1988a, Wernicke et al., $1988 \mathrm{~b}$ ]. Despite the general success of these efforts, important questions remain concerning the age and displacement of major Mesozoic thrust faults in this part of the Cordillera. Many foreland thrusts at this latitude have been intruded by Lower Jurassic plutons or can otherwise be reasonably inferred to have an early Mesozoic age [Dunne, 1986; Burchfiel and Davis, 1988]. West of the foreland thrusts, Dunne [1986] presents evidence for a protracted Jurassic-Cretaceous movement history on thrust faults and folds of the East Sierran thrust system.

In the pre-Tertiary reconstruction of the foreland thrust system proposed by Wernicke et al. [1988a,b], the Funeral Mountains occur in the footwall of the westernmost major foreland structure, the Last Chance thrust [Stewart et al., 1966]. This structure is significant in that it has a very large stratigraphic throw and a minimum displacement of greater than $50 \mathrm{~km}$ [Corbett et al., 1988; Wernicke et al., 1988b]. Unfortunately, the thickness of the Last Chance thrust plate combined with the known stratigraphic thickness of rocks resting above the Monarch Canyon samples in the Funeral Mountains is insufficient to account for more than half of the $30-37 \mathrm{~km}$ of overburden necessary for the Early Cretaceous paleodepths indicated by our study. Moreover, the Last Chance thrust is widely assumed to be of Triassic age [Dunne, 1986;
Corbett et al., 1988], and it seems likely that at least some of the overburden emplaced during Triassic thrusting would have been lost due to erosion by Early Cretaceous time. It is tempting to relate part of the "missing" overburden to movement on thrusts that are structurally higher than the Last Chance thrust, but the Eastem Sierran system is characterized by structures with relatively little stratigraphic throw [Dunne, 1986], and there is no evidence for Cretaceous metamorphism in the Last Chance thrust plate.

The lack of sufficient overburden in the Funeral Mountains leads us to postulate the occurrence of one or more thrust plates of probable Late Jurassic or Early Cretaceous age between the Last Chance thrust plate and the high grade exposures at Monarch Canyon. Existing maps of the northem Funeral Mountains [Troxel and Wright, 1989] show no suitable thrust structures, and we are forced to conclude that the postulated thrust plate os plates have been entirely cut out by subsequent extensional structures such as the Neogene Boundary Canyon detachment (Figure 2).

\section{MECHANISM FOR CRETACEOUS DECOMPRESSION}

Numerical models of P-T-t paths suggest that they can be powerful indicators of tectonic processes during metamorphism [England and Richardson, 1977; England and Thompson, 1984; Royden and Hodges, 1984]. It is possible to define two basic classes of mechanisms by which metamorphic rocks are brought to the surface of the Earth, and each of these results in a distinctive P-T-t trajectory [Hodges, 1988]. The first of these ("C-type") includes erosion as a consequence of crustal thickening [England and Richardson, 1977] and the upward transport of material as a consequence of the development of ramp geometries in structurally lower thrust faults. Assuming purely conductive heat transfer, C-type unroofing paths are characterized by moderate $d P / d T$ and $d T / d t$ slopes after the metamorphic peak. Most of the cooling of samples traversing such paths occurs during exhumation. The second class ("Etype") involves tectonic unroofing as a consequence of movement on structurally higher extensional structures [England and Thompsom, 1986; Ruppel et al., 1988]. Because the rate of tectonic denudation is generally fast compared to that of erosion, E-type paths commonly have high $d P / d T$ slopes over much of the unroofing interval. Most of the cooling of samples subjected to E-type denudation occurs after extension and is characterized by a very high $d T / d t$ slope.

Petrologic and geochronologic data from Monarch Canyon indicate nearly isothermal decompression of Cretaceous age followed by relatively rapid latest Cretaceousearly Tertiary cooling, and it is tempting to suggest that Cretaceous E-type processes played an important role in the unroofing history of the Funeral Mountains. Recent studies in compressional orogens such as the Himalaya [Burchfiel and Royden, 1985; Herren, 1987] and the Alps [Mancktelow, 1985; Platt, 1986; Selverstone, 1988] have led to the recognition of large extensional structures that may have developed to accomodate gravitational collapse of topographic fronts generated by crustal thickening. Several workers have proposed that collapse of an "orogenic welt" developed during Mesozoic compression was largely responsible for Cenozoic extension in the North American Cordillera [e.g., Coney and Harms, 1984; Sonder et al., 1987]. Wernicke et al. [1987] have presented evidence that the time lag between the end of compressional deformation and the beginning of extensional deformation increased from north to south in the Cordillera, 
and was generally smallest in areas of increased Cretaceousearly Tertiary magmatism. If the thermal structure of the overthickened lithosphere governs the timing of extension as Wernicke et al. [1987] and Sonder et al. [1987] suggest, then it seems reasonable to speculate that Mid-to-Late Cretaceous extension may have occured in terrains immediately adjacent to the Sierran arc (e.g., the Funeral Mountains). This hypothesis gains support from the existence of relatively high-temperature extensional fabrics in Monarch Canyon (E. Herren et al., unpublished data, 1988). The presence of Cretaceous extensional structures in the Death Valley area could help explain the "missing" overburden discussed previously.

On the other hand, no large extensional structures of Mesozoic age have been recognized in the Death Valley region, and comparison of the Monarch Canyon P-T path with purely conductive thermal models [e.g., Ruppel et al., 1988] is hampered by the presence of Cretaceous intrusives. Although it is not obvious that granitic intrusions significantly add to the large-scale heat budget in metamorphic terrains [England and Thompson, 1984], it is certainly true that advective heat transfer alters the thermal structure on a local scale [Lux et al., 1986]. This effect is clearly demonstrated in the Monarch Canyon area, where two distinctively different P-T histories can be inferred for samples near Cretaceous intrusions and for samples some distance away. Even though path $A$ in Figure 7 is suggestive of an E-type unroofing mechanism, path B is equally consistent with C-type denudation. Moreover, it is possible to generate trajectories similar to path $\mathbf{A}$ in a C-type situation by injecting melts into the system (thereby adding heat) during uplift. Until the local effects of Cretaceous intrusions can be subtracted from the overall thermal structure of the Funeral Mountains, perhaps by detailed studies of the PT-t history of lower-grade, intrusive-free portions of the metamorphic core, the mechanism of Cretaceous unroofing remains enigmatic.

\section{LIMTS ON NEOGENE E-TYPE DENUDATION}

Regardless of the cause of Cretaceous uplift, the P-T data presented here place firm constraints on the amount of E-type unroofing that could have occurred during Neogene Basin and Range extension. Final equilibration of samples FM-14 and FM-18 at pressures of 430 to $440 \mathrm{MPa}$ suggests a depth of roughly $16 \mathrm{~km}$ for the Monarch Canyon area in Late Cretaceous time. Thick, largely preextensional Oligocene-Miocene fanglomerate sequences in the southem Funeral Mountains and eastern Grapevine Mountains [Reynolds, 1974; Cemen et al., 1985] suggest that at least some of the Late Cretaceous overburden was eroded away prior to late Cenozoic extension. Consequently, an absolute maximum of $15 \mathrm{~km}$ of cover may have been removed from the Funeral Mountains by tectonic denudation in Neogene time.

\section{CONCLUSIONS}

Rim thermobarometry and P-T path modeling of pelitic samples from the Monarch Canyon area suggest peak metamorphic conditions of $800-850 \mathrm{~K}$ and $800-1000 \mathrm{MPa}$, followed by as much as $600 \mathrm{MPa}$ of broadly isothermal decompression. Available geochronologic data [DeWitt et al., 1988] suggests that the metamorphic peak occurred in Early Cretaceous time and that the low-pressure terminus of the P-T path corresponds to conditions in Late Cretaceous time. The average unroofing rate over the Early to Late Cretaceous interval was approximately $0.5 \mathrm{~mm} / \mathrm{yr}$.
Our data require tectonic burial of the Monarch Canyon area to depths of more than $30 \mathrm{~km}$ in Early Cretaceous time. The structures responsible for this burial remain cryptic, but we postulate that one or more Early Cretaceous thrust plates above the Funeral Mountains have been excised by post-Early Cretaceous extensional structures. These include Neogene faults like the Boundary Canyon detachment, but the morphology of the P-T path derived in this study raises the intriguing possibility that some tectonic unroofing may have occurred in Middle to Late Cretaceous time.

Acknowledgments. We would like to express our appreciation to Tim Coonan, Peter Rowlands, Pete Sanchez, and the entire NPS staff at Death Valley National Monument, who make field work in the Funeral Mountains logistically feasable. Extensive discussions with Clark Burchfiel, Eveline Herren, Larry McKenna, Ed DeWitt, John Sutter, Bennie Troxel, Brian Wernicke, and Lauren Wright have heightened our understanding of the Death Valley region. Ed DeWitt and John Sutter kindly gave us permission to quote their ${ }^{40} \mathrm{Ar}-{ }^{39} \mathrm{Ar}$ results in advance of publication, and Lauren Wright provided preprints of map comilations for the Funeral Mountains. DeWitt, Sutter, and Wright made constructive comments on early drafts of this manuscript. Lawford Anderson and Ron Frost provided thoughtful and exhaustive reviews of the penultimate version. None of the reviewers should be held responsible for the heresies espoused in the final paper. Our work in Death Valley is supported by the National Science Foundation through research grants EAR-8721258 and EAR-8816950.

\section{REFERENCES}

Anderson, J.L., A.P. Barth and E.D. Young, Mid-crustal Cretaceous roots of Cordilleran metamorphic core complexes, Geology, 16, 366-369, 1988.

Armstrong, R.L., Cordilleran metamorphic core complexes - From Arizona to southem Canada, Annu. Rev. Earth Planet. Sci., 10, 129-154, 1982.

Bohlen, S.R., V.J. Wall, and A.L. Boettcher, Experimental investigations and geological applications of equilibria in the system $\mathrm{FeO}-\mathrm{TiO}_{2}-\mathrm{Al}_{2} \mathrm{O}_{3}-\mathrm{SiO}_{2}-\mathrm{H}_{2} \mathrm{O}$., Am. Mineral., 68, 1049 $1058,1983$.

Burchfiel, B.C. and G.A. Davis, Mesozoic thrust faults and Cenozoic low-angle normal faults, eastem Spring Mountains, Nevada, and Clark Mountains thrust complex, Califomia, in This Extended Land: Geological Journeys in the Southern Basin and Range, edited by D.L. Weide and M.L. Faber, pp. 87-106, Department of Geoscience, University of Nevada at Las Vegas, Las Vegas, 1988.

Burchfiel, B.C., and L.H. Royden, North-south extension within the convergent Himalayan region., Geology, 13, 679-682, 1985.

Cemen, I., L.A. Wright, and R.E. Drake, Cenozoic sedimentation and sequence of deformational events at the southeastem end of the Fumace Creek strike-slip fault zone, Death Valley region, California, in Strike-Slip Deformation, Basin Formation, and Sedimentation, edited by K.T. Biddle and N. Christie-Blick, PP. 127-141, Soc. Econ. Paleontol. Mineral., Denver, 1985.

Coney, P.J., and T.A. Harms, Cordilleran metamorphic core complexes: Cenozoic extensional relics of Mesozoic compression., Geology, 12, 550-554, 1984.

Corbett, K., C.T. Wrucke, and C.A. Nelson, Structure and tectonic history of the Last Chance thrust system, Inyo Mountains and Last Chance Range, Califomia, in This Extended Land, Geological Journeys in the Southern Basin and Range, Field Trip Guidebook, edited by D.L. Weide and M.L. Faber, Pp. 269-292, Department of Geoscience, University of Nevada at Las Vegas, Las Vegas, 1988.

DeWitt, E., J.F. Sutter, L.A. Wright, and B.W. Troxel, Ar-Ar chronology of Early Cretaceous regional metamorphism, Funeral Mountains, California--A case study of excess argon, Geol. Soc. Am. Abstr. w. Programs, 20, A16-A17, 1988.

Dunne, G.C., Geologic evolution of the southerm Inyo Range, Darwin Plateau, and Argus and Slate Ranges, east-central Califomia: An overview, in Mesozoic and Cenozoic Structural Evolution of Selected Areas, East-Central California, Field Trip Guidebook, edited by G.C. Dunne, pp. 3-21, Cordilleran Section, Geological Society of America, Boulder, 1986.

England, P.C. and S.W. Richardson, The influence of erosion upon mineral facies of rocks from different metamorphic environments, J. Geol. Soc. London, 134, 201-213, 1977. 
England, P.C., and A.B. Thompson, Pressure-temperature-time paths of regional metamorphism I. Heat transfer during the evolution of regions of thickened continental crust, J. Petrol., 25, 894-928, 1984.

England, P.C. and A.B. Thompson, Some thermal and tectoric models for crustal melting in continental collision zones., in ollision Tectonics, edited by M.P. Coward and A.C. Ries, $p_{k}$ 83-94, Blackwell, Oxford, 1986.

Ferry, J.M. and F.S. Spear, Experimental calibration of the partitioning of $\mathrm{Fe}$ and $\mathrm{Mg}$ between biotite and gamet, Contrib. Mineral. Petrol., 66, 113-117, 1978.

Gasparik, T., Experimental study of the subsolidus phase relations and mixing properties of pyroxene in the system $\mathrm{CaO}-\mathrm{Al}_{2} \mathrm{O}_{3}-\mathrm{SiO}_{2}$, Geochim. Cosmochim. Acto, 48, 2537-2545, 1984

Goldsmith, J.R., Melting and breakdown reactions of anorthite at high pressures and temperatures., Am. Mineral., 65, 272-284, 1980.

Hariya, Y., and G.C. Kennedy. Equilibrium study of anorthite under high temperature and high pressure, Am. J. Sci., 266, 193-203, 1968.

Hays, J.F., Lime-alumina-silica., YearBook Carnegie Inst. Washington Yearbook, 65, 234-239, 1966.

Herren, E., Zanskar shear zone: Northeast-southwest extension within the Higher Himalayas (Ladakh, India), Geology, 15, 409-413, 1987.

Hodges, K.V., Metamorphic and geochronologic constraints on the uplift history of Cordilleran metamorphic core complexes, Geol. Soc. Am. Abs. w. Programs, 20, A18, 1988.

Hodges, K.V., and L.W. McKenna, Realistic propagation of uncertainties in geologic thermobarometry, Am. Mineral., 72, $671-680,1987$.

Hodges, K.V. and L.H. Royden, Geologic thermobarometry of retrograded metamorphic rocks: An indication of the uplift trajectory of a portion of the northem Scandinavian Caledonides, J. Geophys. Res., 89, 7077-7090, 1984.

Holdaway, M.J., Stability of andalusite and the aluminosilicate phase diagram, Am. J. Sci., 271, 97-131, 1971.

Indares, A. and J. Martignole, Biotite-gamet geothermometry in the granulite facies: The influence of $\mathrm{Ti}$ and $\mathrm{Al}$ in biotite, $A \mathrm{~m}$. Mineral., 70, 272-278, 1985.

Jäger, E., Introduction to geochronology, in Lectures in Isotope Geology, edited by E. Jäger and J.C. Hunziker, pp. 1-12, SpringerVerlag, New York, 1979.

Koziol, A.M. and R.C. Newton, Redetermination of the anorthite breakdown reaction and improvement of the plagioclase-garnet$\mathrm{Al}_{2} \mathrm{SiO}_{5}$-quartz geobarometer, Am. Mineral., 73, 216-223, 1988.

Labotka, T.C., Petrology of a medium-pressure regional metamorphic terrane, Funeral Mountains, California, Am. Mineral., 65, 670$689,1980$.

Labotka, T.C., and A.L. Albee, Metamorphism and tectonics of the Death Valley region, California, in Metamorphism and Crustal Evolution of the Western United States, edited by W.G. Emst, Pp. 714-736, Prentice-Hall, Englewood Cliffs, N.J., 1988.

Lux, D.R., J.J. DeYoreo, C.V. Guidotti, and E.R. Decker, Role of plutonism in low-pressure metamorphic belt formation, Nature, 323, 794-797, 1986.

Mancktelow, N., The Simplon line: A major displacement zone in the western Lepontine Alps, Eclogae Geol. Helv., 78, 73-96, 1985.

McKenna, L.W. and K.V. Hodges, Accuracy versus precision in locating reaction boundaries: Implications for the gametplagioclase-aluminum silicate-quartz geobarometer, Am. Mineral., 73, 1205-1208, 1988

Platt, J.P., Dynamics of orogenic wedges and the uplift of highpressure metamorphic rocks, Geol. Soc. Am. Bull., 97, 10371053, 1986.

Reynolds, M.W., Geology of the Grapevine Mountains, Death Valley. Califomia: A summary, in Guidebook: Death Valley Region, California and Nevada, edited by B.W. Troxel, pp. 92-97,
Cordilleran Section, Geological Society of America, Boulder, 1974.

Reynolds, M.W., L.A. Wright, and B.W. Troxel, Geometry and chronology of late Cenozoic detachment faulting, Funeral and Grapevine Mountains, Death Valley, California, Geol. Soc. Am. Abs. w. Programs, 18, 175, 1986.

Royden, L.H., and K.V. Hodges, A technique for analyzing the thermal and uplift histories of eroding orogenic belts: A Scandinavian example, J. Geophys. Res., 89, 7091-7106, 1984.

Ruppel, C., L. Royden, and K.V. Hodges, Thermal modeling of extensional tectonics: Application to pressure-temperature-time histories of metamorphic rocks, Tectonics, 7, 947-957, 1988.

Selverstone, J., Evidence for east-west crustal extension in the Eastem Alps: Implications for the unroofing history of the Tauem Window, Tectonics, 7, 87-105, 1988.

Sonder, L.J., P.C. England, B.P. Wemicke, and R.L. Christiansen, A physical model for Cenozoic extension of westem North America in Continental Extensional Tectonics, edited by M.P. Coward, J.F. Dewey, and P.L. Hancock, PP. 187-201, Geological Society of London, Oxford, 1987.

Spear, F.S., and J. Selverstone, Quantitative P-T paths from zoned minerals: theory and tectonic applications, Contrib. Mineral Petrol., 83, 348-357, 1983.

Stewart, J.H., $\mathrm{E}$ tensional tectonics in the Death Valley area, Califomia: Trunsport of the Panamint Range structural block 80 km northwestward., Geology, 11, 153-157, 1983.

Stewart, J.H., D.C. Ross, C.A. Nelson, and B.C. Burchfiel, Last Chance thrust - A major fault in the eastem part of Inyo County, California, U.S. Geol. Surv. Prof. Pap., 550-D, D23-D34, 1966.

Troxel, B.W., A geologic traverse of the northem Funeral Mountains, Death Valley, Califomia, in This Extended Land, Geological Journeys in the Southern Basin and Range, Field Trip Guidebook, edited by D.L. Weide, and M.L. Faber, Pp. 45-49, Cordilleran Section, Geological Society of America, Boulder, 1988.

Troxel, B.W., and L.A. Wright, Geologic map of the central and northem Funeral Mountains and adjacent areas, Death Valley Region, southem Califomia, US. Geol. Surv. Open-File Report, $89-348,1989$.

Wasserburg, G.J., G.W. Wetherill, and L.A. Wright, Ages in the Precambrian terrain of Death Valley, California, J. Geol., 67, 702$708,1959$.

Wemicke, B., G.J. Axen, and J.K. Snow, Basin and Range extensional tectonics at the latiude of Las Vegas, Nevada, Geol. Soc. Am. Bull., 100, 1738-1757, 1988a.

Wernicke, B.P., R.L. Christiansen, P.C. England, and L.J. Sonder Tectonomagmatic evolution of Cenozoic extension in the North American Cordillera, in Continental Extensional Tectonics, edited by M.P. Coward, J.F. Dewey, and P.L. Hancock, Pp. 203-221, Geological Society of London, Oxford, 1987.

Wernicke, B.P., J.K. Snow, and J.D. Walker, Correlation of early Mesozoic thrusts in the southem Great Basin and their possible indication of $250-300 \mathrm{~km}$ of Neogene crustal extension, in This Extended Land, Geological Journeys in the Southern Basin and Range, Field Trip Guidebook, edited by D.L. Weide, and M.L. Faber, pp. 255-267, Cordilleran Section, Geological Society of America, Boulder, $1988 b$.

K.V. Hodges, Department of Earth, Atmospheric, and Planetary Sciences, Massachusetts Institute of Technology, Cambridge, MA 02139.

J.D. Walker, Department of Geology, University of Kansas, Lawrence, KS 66045.

(Received June 20, 1989

revised September 7, 1989;

accepted September 18, 1989.) 